\title{
Glycemic Index and Glycemic Load in Children and Adolescents and its Association with Obesity and Diabetes
}

\author{
Regiane Lopes de Sales* and EvenJheice Calixto de Oliveira \\ University of Viçosa campus Rio Paranaíba, Brazil
}

Submission: March 14, 2018; Published: April 03, 2018

*Corresponding author: Regiane Lopes de Sales, Universidade Federal de Viçosa campus Rio Paranaíba. MG 230 Km 7, Rio Paranaíba -MG, Brazil, Tel/Fax: +55 34 3855-9300; Email: regianesales@gmail.com

\begin{abstract}
Insulin resistance acts as the link between different pathologies, such as obesity, dyslipidemia, hypertension and type 2 diabetes. In this context, the consumption of diets with a high glycemic index and glycemic load are associated with the development of these chronic noncomuncable diseases. Recently, children and adolescents are being affected by these diseases. This raises the questioning if controlling the glycemic index and glycemic load of the diet would be preventing the future development of these pathologies. This review discusses this controversial topic
\end{abstract}

Keywords: Glycemic index; Glycemic load; Diabetes; Obesity

\section{Introduction}

The prevalence of overweight and obesity has dramatically increased in the last 30 years and been regarded as a pandemic disease. In many countries, more than half of the adult population is overweight or obese [1]. Although genetic factors may contribute to these conditions, they do not explain such drastic change in nutritional epidemiology. Decrease in physical activity, combined with increased access to highly energetic, palatable, and relatively cheap foods of low nutritional value, and decreased consumption of whole foods, may explain this nutrition transition [2].

\section{Obesity and diabetes in children and adolescents}

This process has been witnessed not only in adults, but also among children and adolescents. Chronic non-communicable diseases, which until very recently were considered typical of adult and elderly population, have been increasingly common in young individuals. Obesity, type 2 diabetes, dyslipidemias and hypertension have been reported in children and adolescents in several reports $[3,4]$. Eating habits exert an important influence on the cause of these diseases, which have insulin resistance as a common starting point. Childhood is a crucial stage in the development of healthy dietary habits. Nevertheless, high consumption of high-sugar, processed foods, low in fiber and

micronutrients, including candies, processed juice, salty snacks, sweets, cake, and refined cereals, all with a high glycemic index (GI), has been reported during this age.

\section{Glycemic index and glycemic load}

Since glucose levels are directly related with insulin production, GI was created as a tool to help control diet quality, and thereby prevent or delay the progression of chronic diseases associated with altered insulin production and insulin resistance, such as diabetes mellitus [5,6], metabolic syndrome [7], obesity [8] and some cancers [9].

Nevertheless, the standardized method to calculate GI, i.e., based on a fixed $(50 \mathrm{~g})$ amount of carbohydrates, received criticism, since most carbohydrate-containing foods do not provide $50 \mathrm{~g}$ of carbohydrate in their typical serving size [10]. Thus, since in a real-life situation, neither the amount of carbohydrate consumed nor the time for its ingestion is controlled, another parameter, named glycemic load (GL), was proposed [11] to estimate blood glucose response to carbohydrate consumption, considering food serving portions typically consumed in daily life [12].

Clinical studies have suggested an important role of GI in energy metabolism $[5,13]$. Consumption of high GL and GI 


\section{Current Research in Diabetes \& Obesity Journal}

foods induces a high glycemic and insulin response, resulting in greater cellular glucose uptake and fall in circulating glucose level, which may be associated with higher hunger sensation and consequently greater food consumption [13-15]. Besides, consumption of high GI and high GL diets can alter lipid profile and favor the development of cardiovascular diseases. Insulin resistance has been suggested as the triggering event for LDL uptake from the blood, body weight gain, and peripheral vascular resistance, common in diabetes mellitus, obesity, hypertension and dyslipidemias $[5,16,17]$.

On the other hand, low GI diets have been associated with slower glucose removal rates and hence lower glucose fluctuation, which in turn, leads to a better glycemic control. In type 2 diabetes, low GI diets were associated with lower glycated hemoglobin and fructosamine levels, two key biomarkers of glycemic control $[16,18]$. In addition, consumption of low GI foods leads to the release of counterregulatory hormonescortisol, growth hormone and glucagon. Body fat mass regulation associated with the consumption of low GI diets seems to be correlated with the activation of some genes. For example, these diets seem to decrease the expression of ob gene, resulting in lower postprandial insulin secretion $[13,19]$. In a review article [20], the adoption of a low GL diet is suggested as a dietetic strategy to prevent metabolic syndrome.

Several studies have investigated the impact of GI and GL on health $[13,16,19,21]$. However, despite their established importance, the use of these parameters is not a consensus and results of clinical studies are still conflicting [10,13,21]. Glucose absorption is also influenced by other dietary components, including lipid, protein and fiber. In addition to its chemical composition, other factors such as the size of carbohydrate particles and food processing methods may also affect carbohydrate digestion and absorption rates [23].

In general, high GI diets are rich in refined carbohydrates, and poor in fiber, protein and micronutrients, in contrast to low GI diets, rich in micronutrients and fibers. This makes it practically impossible to conduct comparative studies on diets with the same amounts of these nutrients and different GI and GL [24]. However, it is worth pointing out that this relationship between GI/GL and other nutrients may vary between different cultures. In a study on Japanese children, low GI/GL was positively correlated with salt and saturated fat intake [25]. In another study involving adults in Spain, GL was positively correlated with lower BMI [26]. Therefore, despite beneficial effects of low GI/GL diets on nutrient incorporation and glycemic control, one should also consider different dietary patterns adopted in the countries. For example, although the incidence of obesity and diabetes is known to be lower in Japan than in Western countries, a recent study showed that Japanese children follow relatively higher GI/ GL diets as compared with these countries [25].

\section{Conclusion}

Nationwide studies on GI and GL diets in children and adolescents have been conducted in few countries and are still scarce [27-29]. More attention should be addressed to the theme to clarify whether the adoption of low GI and GL diets in children could actually contribute to stopping the expansion of diabetes and obesity in the world.

\section{References}

1. World Health Organization WHO (2016) Global database on body mass index an interactive surveillance tool for monitoring nutrition transition.

2. Althoff T, Socič R, Hicks JL, King AC, Delp SL, et al. (2017) Large-scale physical activity data reveal worldwide activity inequality. Nature 547(7663): 336-339.

3. Hannom TS, Rao G, Arslanian SA (2005) Childood obesity and type 2 diabetes mellitus. Pediatr 116(2): 473-480.

4. Xue Y, Gao Y (2016) Childhood type 2 diabetes: Risks and complications (Review). Exp Ther Med 12(4): 2367-2370.

5. Macdonald IA (2016) A review of recent evidence relating to sugars, insulin resistance and diabetes. Eur J Nutr 55(suppl 2): S17-S23.

6. Akash H, Rehman K, Liagat A (2018) Tumor necrosis factor-alpha: Role in development of insulin resistance and pathogenesis of type 2 diabetes mellitus. J Cell Biochem 119(1): 105-110.

7. Barba G, Sieri S, Russo MD, Donatiello E, Formisano A, et al. (2012) Glycaemic index and body fat distribution in children: The results of the ARCA projet. Nutr, Metab Cardiov Diseas 22(1): 28-34.

8. Kyungjoon L, Jackson KL, Sata Y, Head GA (2017) Factors responsible for obesity-related hypertension. Curr Hypertens Rep 19(7): 53.

9. Twarock S, Reichert C, Peters U, Gorski DJ, Röck K, et al. (2017) Hyperglycaemia and aberrant insulin signaling stimulate tumor progression via induction of the extracellular matrix component hyaluronan. Int J Cancer 141(4): 791-804.

10. Sacks FM, Carey VJ, Anderson CAM, Miller III ER, Copeland T, et al. (2014) Effects of high vs low glycemic index of dietary carbohydrate on cardiovascular disease risk factors and insulin sensitivity. JAMA 312(23): 2531-2541.

11. Salmeron J (1997) Dietary Fiber, Glycemic Load, and risk of non-insulin-dependent diabetes mellitus in women. JAMA 277(6): 472-477.

12. Barclay AW, Brand Miller JC, Wolever TM (2005) Glycemic index, glycemic load, and glycemic response are not the same. Diabetes Care 28(7): 1839-1840.

13. Silva FM, Kramer CK, Crispim D, Azevedo MJ (2015) A high-glycemic index, low fiber breakfast affects the postprandial plasma glucose, insulin, and ghrelin responses of patientes with Type 2 Diabetes in a randomized clinical trial. J Nutr 145(4): 736-741.

14. Tsilas CS, Souza RJ, Mejia SB, Mirrahimi A, Cozma AI, et al. (2017) Relation of total sugars, fructose and sucrose with incident type 2 diabetes: a systematic review and meta-analysis of prospective cohort studies. CMAJ 189(20): E711-E720.

15. Sun FH, Li C, Zhang YJ, Wong SH, Wang L (2016) Effect of glycemic index of breakfast on energy intake at subsequent meal among healthy people: a meta-analysis. Nutrients 8(1): 37 .

16. Cheng G, Xue H, Luo J, Hong J, Zhang L, et al. (2017) Relevance of the dietary glycemic index, glycemic load and genetic predisposition for 


\section{Current Research in Diabetes \& Obesity Journal}

the glucose homeostasis of Chinese adults without diabetes. Sci Rep $7(1): 400$.

17. Stojkovic V, Simpson CA, Sullivan RR, Cusano AM, Kerstetter JE, et al. (2017) The effect of dietary glycemic properties on markers of inflammation, insulin resistance, and body composition in postmenopausal American women: an ancillary study from a multicenter protein supplementation trial. Nutrients 9(5): 1-10.

18. Wang Q, Xia W, Zhao Z, Zhang H (2015) Effects comparison between low glycemic index diets and high glycemic index diets on HbA1c and fructosamine for patients with diabetes: A systematic review and meta-analysis. Prim Care Diabetes 9(5): 362-369.

19. Ebbeling CB, Leidig MM, Sinclair KB, Hangen JP, Ludwig DS (2003) A reduced-glycemic load diet in the treatment of adolescent obesity. Arch Pediatr Adolesc Med 157(8): 773-779.

20. de la Iglesia R, Loria-Kohen V, Zulet MA, Martinez JA, Reglero G, et al. (2016) Dietary strategies implicated in the prevention and treatment of metabolic syndrome. Int J Mol Sci 17(11): pii: E 1877.

21. Dias VM, Pandini JA, Nunes RR, Sperandei SLM, Portella ES, et al (2010) Influência do índice glicêmico da dieta sobre parâmetros antropométricos e bioquímicos em pacientes com diabetes tipo 1. Arq Bras Endocrionol Metab 54(9): 801-806.

22. Guttierres APM, Alfenas RCG (2007) Efeitos do índice glicêmico no balanço energético. Arq Bras Endocrinol Metab 51(3): 382-388.
23. Sartorelli DS, Cardoso MA (2006) Associação entre carboidratos da dieta habitual e diabetes mellitus tipo 2: evidências epidemiológicas. Arq Bras Endocrinol Metab 50(3): 415-426.

24. Eleazu CO (2016) The concept of low glycemic index and glycemic load foods as panacea for type 2 diabetes mellitus; Prospects, challenges and solutions. Afr Health Sci 16(2): 468-479.

25. Murakami K, Sasaki S (2018) A low-glycemic index and -glycemic load diet is associated with not only higher intakes of micronutrients but also higher intakes of saturated fat and sodium in Japanese children and adolescentes: the National Health and Nutrition Survey. Nutr Res 49(1): 37-47.

26. Mendez MA, Covas MI, Marrugat J, Vila J, Schroder H (2009) Glycemic load, glycemic index and body mass index in Spanish adults. Am J Clin Nutr 89(1): 316-322

27. Hui LL, Nelson EAS (2006) Meal glycaemic load of normal-weight and overweight Hong Kong children. Eur J Clin Nutr 60(2): 220-227.

28. Jones M, Barclay AW, Brand Miller JC, Louie JC (2016) Dietary glycaemic index andglycaemic load among Australian children and adolescents: results from the 2011-2012 Australian health survey. Br J Nutr 116(1): 178-187

29. Murakami K, McCaffrey TA, Livingstone MBE (2013) Dietary glycaemic index and glycaemic load in relation to food and nutrient intake and indices of body fatness in British children and adolescents. Br J Nutr 110(8): 1512-1523.

Your next submission with Juniper Publishers
will reach you the below assets
- Quality Editorial service
- Swift Peer Review
- Reprints availability
- E-prints Service
- Manuscript Podcast for convenient understanding
- Global attainment for your research
- Manuscript accessibility in different formats
( Pdf, E-pub, Full Text, Audio)
- Unceasing customer service
Track the below URL for one-step submission
https://juniperpublishers.com/online-submission.php

